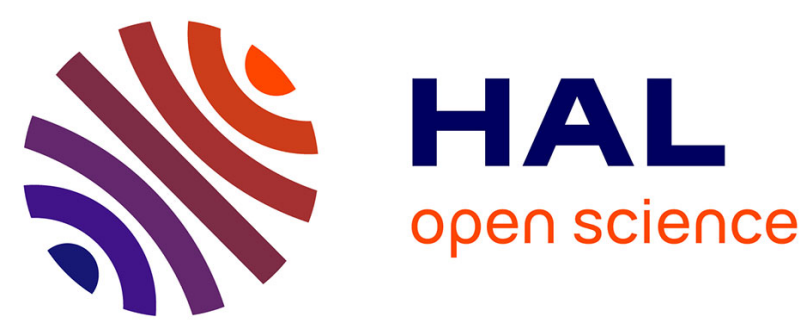

\title{
Diagenesis and benthic fluxes of nutrients and metals during experimentally induced anoxia in the Gulf of Trieste (northern Adriatic Sea)
}

Neža Koron, Nives Ogrinc, E. Metzger, Bettina Riedel, Jadran Faganeli

\section{To cite this version:}

Neža Koron, Nives Ogrinc, E. Metzger, Bettina Riedel, Jadran Faganeli. Diagenesis and benthic fluxes of nutrients and metals during experimentally induced anoxia in the Gulf of Trieste (northern Adriatic Sea). Biogeosciences Discussions, 2013, 10 (7), pp.11729-11755. 10.5194/bgd-10-11729-2013 . hal-03278280

\section{HAL Id: hal-03278280 \\ https://univ-angers.hal.science/hal-03278280}

Submitted on 17 Jul 2021

HAL is a multi-disciplinary open access archive for the deposit and dissemination of scientific research documents, whether they are published or not. The documents may come from teaching and research institutions in France or abroad, or from public or private research centers.
L'archive ouverte pluridisciplinaire HAL, est destinée au dépôt et à la diffusion de documents scientifiques de niveau recherche, publiés ou non, émanant des établissements d'enseignement et de recherche français ou étrangers, des laboratoires publics ou privés. 


\title{
Diagenesis and benthic fluxes of nutrients and metals during experimentally induced anoxia in the Gulf of Trieste (northern Adriatic Sea)
}

\author{
N. Koron ${ }^{1}$, N. Ogrinc $^{2}$, E. Metzger ${ }^{3}$, B. Riedel ${ }^{4}$, and J. Faganeli ${ }^{1}$
}

${ }^{1}$ National Institute of Biology, Marine Biological Station, Fornače 41, 6330 Piran, Slovenia ${ }^{2}$ Jožef Stefan Institute, Department of Environmental Sciences, Jamova 39, 1000 Ljubljana, Slovenia

${ }^{3}$ LUNAM Université, Université d'Angers, UMR CNRS 6112 LPGN-BIAF-Laboratoire des Bio-Indicateurs Actuels et Fossiles, 2 Boulevard Lavoisier, 49045 Angers Cedex, France ${ }^{4}$ University of Vienna, Department of Limnology and Oceanography, Althanstrasse 14, 1090 Vienna, Austria

Received: 30 June 2013 - Accepted: 2 July 2013 - Published: 15 July 2013

Correspondence to: N. Ogrinc (nives.ogrinc@ijs.si)

Published by Copernicus Publications on behalf of the European Geosciences Union.

Diagenesis and benthic fluxes of nutrients and metals

N. Koron et al.

\section{Title Page}

Abstract Introduction

Conclusions References

Tables Figures

14 $\rightarrow 1$

4

Back Close

\section{Full Screen / Esc}

Printer-friendly Version

Interactive Discussion 


\section{Abstract}

Sequential nutrient regeneration and organic matter (OM) degradation in surface sediments of the Gulf of Trieste (northern Adriatic Sea) were examined using in situ benthic chambers under normoxic, anoxic and reoxic conditions. Intensive $\mathrm{NH}_{4}^{+}$and

$5 \mathrm{PO}_{4}^{3-}$ anoxic regeneration was subsequently slower in prolonged anoxia. $\mathrm{NH}_{4}^{+}$production was probably also a consequence of dissimilatory nitrate reduction to $\mathrm{NH}_{4}^{+}$. The presence of anammox and laterally pumping of oxygenated water by benthic infauna explained the presence of $\mathrm{NO}_{3}^{-}$in anoxia. Anoxic phases were characterized by enhanced dissolution of $\mathrm{Si}_{\text {biog }}$, decreasing pore water $\mathrm{Ca}$ and $\mathrm{Mg}$ concentrations 10 indicating carbonate precipitation and higher Fe and $\mathrm{Mn}$ concentrations as a result of reduction/respiration. Reoxygenation was characterized by enhanced bioturbation. $\mathrm{Ni}$ trification caused $\mathrm{NH}_{4}^{+}$decrease and $\mathrm{P}$ precipitated quickly as carbonate fluorapatite and $\mathrm{FePO}_{4}$. In addition adsorption of $\mathrm{P}$ onto Fe-hydroxides could also occur since $\mathrm{Fe}$ (and $\mathrm{Mn}$ ) reoxidized quickly. Increased Ca levels suggested enhanced carbonate dis15 solution. Diffusive fluxes at the sediment-water interface (SWI), calculated from pore water modelling using diffusion-reaction model, revealed high anoxic $\mathrm{NH}_{4}^{+}$effluxes and $\mathrm{Ca}$ (and $\mathrm{Mg}$ ) influxes. $\mathrm{PO}_{4}^{3-}$ fluxes were very low and high $\mathrm{NH}_{4}^{+} / \mathrm{PO}_{4}^{3-}$ flux ratios in anoxic and reoxic phases suggested an excess of benthic inorganic $\mathrm{N}$. Nutrient budgets at the SWI showed intensive anoxic recycling of inorganic $\mathrm{N}$ but low $\mathrm{P}$ and $\mathrm{Si}$ cycling in all redox phases.

\section{Introduction}

The Gulf of Trieste is an example of shallow coastal marine environments that are characterized by relatively low organic matter (OM) contents in sediments (Ogrinc et al., 2005). The largest fraction of sedimentary OM originates from the pelagic production, remainder originates from benthic primary production, which represents a significant

Diagenesis and benthic fluxes of nutrients and metals

N. Koron et al.

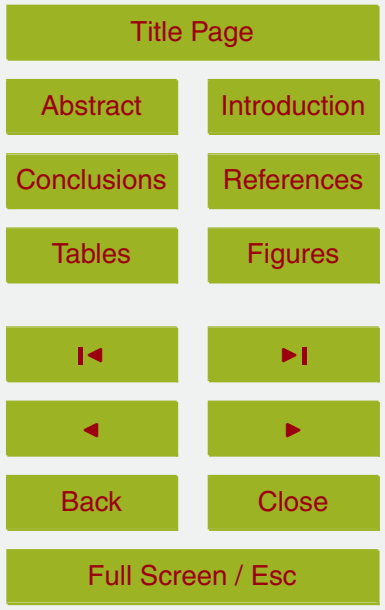

Printer-friendly Version

Interactive Discussion 
source of easily degradable $\mathrm{OM}$ in this environment due to the euphotic zone reaching the bottom (Kemp et al., 1999; Welker et al., 2001). The autochthonous (marine) origin of OM is confirmed by its $\delta^{13} \mathrm{C}_{\text {org }}$ values (Faganeli et al., 1991; Ogrinc et al., 2005). The Gulf, becoming recently oligotrophic, experiences two phytoplankton blooms yearly oc5 curring in spring and autumn (Mozetič et al., 2012). The first is a consequence of increased nutrient-rich fresh water inflow into the Gulf, whereas the autumn bloom follows disruption of the stratified summer water column, and thus releases of the trapped nutrients. Benthic microalgae exhibit summer peaks due to the highest release of nutrients from pore waters (Welker et al., 2002).

10 Vertical stratification of water masses in the gulf lead to $\mathrm{O}_{2}$ depletion in the bottom water layers causing hypoxia and even anoxia (Kemp et al., 1999). Coastal hypoxia and anoxia are widespread and increasingly common events that can result in seasonal or even persistent "dead zones" (Diaz and Rosenberg, 2008), which are also known in the Gulf of Trieste (Faganeli et al., 1985; Stachowitsch, 1991; Riedel et al., 2008). 15 These can influence the biogeochemical processes taking place in sediment by marine microorganisms and influenced by activities of benthic infauna. The latter include changes in sediment burrowing and reworking by benthic invertebrates (Aller, 1982). In sediments of the Gulf of Trieste, the most important macrofauna are sea urchins, brittle stars and polychaetes (Ogorelec et al., 1991; Stachowitsch et al., 2007). Their activities influence nutrient release and the redox cycling of elements at the sediment-water interface (SWI) (Hunter et al., 2012). With the occurrence of hypoxia or even anoxia, the activity of sediment infauna decreases limiting the sediment reworking and reoxidation of reduced chemical species originating from deeper sediment layers where anoxic OM mineralization takes place (Aller and Yingst, 1988; Hines et al., 1997). This leads to a migration of reductive layers upwards and enhances the importance of sulfate reduction in the topmost sediment layers. Due to the accumulation of toxic hydrogen sulfide, the mortality of benthic macrofauna increases and the decaying biomass acts as an additional source of "fresh" easily degradable OM.
BGD

10, 11729-11755, 2013

Diagenesis and

benthic fluxes of

nutrients and metals

N. Koron et al.

Title Page

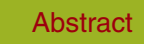

Introduction

Conclusions

References

Tables

Figures

14

- I

4

Back

Close

Printer-friendly Version

Interactive Discussion 
The aim of this study was to simulate anoxia and reoxidation for variable amount of time in order to investigate the consequences of shifts in benthic biogeochemical processes using the changes of pore water composition of nutrients and metals encompassing oxic and anoxic conditions and subsequent recovery. Since the composition of 5 pore water serves as a sensitive indicator of early diagenetic reactions (Berner, 1980), it was the primary focus of this research. This study was a part of a broader project entitled "Low dissolved oxygen events in the Northern Adriatic: in situ experimental insights into multi-level responses before, during and post-anoxia" with its main objectives being a behavior, mortality and regeneration of infauna community in extreme conditions.

10 The recovery of deteriorated marine environment, which experiences severe anoxia events is usually slow. Sedimentary biogeochemical data were used also as a proxy for evaluating environmental status in such extreme conditions and as a tool for projection of environmental consequences induced by anoxia. The results also allow us to discuss the consequences of advanced remineralization in a relatively organic poor

\section{Materials and methods}

\subsection{Study area}

The study site was located $2.3 \mathrm{~km}$ off Piran (Slovenia) in the southern part of the Gulf of Trieste (northern Adriatic Sea) at the Marine Biological Station hydrographic buoy Vida $\left(45^{\circ} 32.300^{\prime} \mathrm{N}, 13^{\circ} 33.000^{\prime} \mathrm{E}\right)$. This northernmost part of the Adriatic Sea is covering an area of $500 \mathrm{~km}^{2}$ with a maximal depth of $25 \mathrm{~m}$ and is isolated from the rest of northern Adriatic by a shoal. The salinity of bottom waters ranges from 36 to 38.5 and bottom water temperatures range from $8{ }^{\circ} \mathrm{C}$ in winter and $20^{\circ} \mathrm{C}$ in summer. A density gradient in late summer can result in bottom water layer hypoxia and even anoxia (Faganeli et al., 1985). Sediment in the southern part of the Gulf is composed mainly of silty sand that is high in biogenic carbonate, populated mostly by brittle stars, sponges and

BGD

10, 11729-11755, 2013

Diagenesis and

benthic fluxes of

nutrients and metals

N. Koron et al.

Title Page

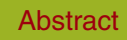

Introduction

Conclusions

Tables

References

Figures

14

$\rightarrow$

4

Back

Close

Full Screen / Esc

Printer-friendly Version

Interactive Discussion

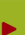


tunicates and actively bioturbated by polychaetes and bivalves (Ogorelec et al., 1991). The sedimentation rate, determined using ${ }^{210} \mathrm{~Pb}$, is approximately $1.2 \mathrm{mmyr}^{-1}$ in the central part of the gulf increasing up to $3 \mathrm{~mm} \mathrm{yr}^{-1}$ towards the shore (Ogorelec et al., 1991). The sediment surface is populated by microalgae composed mostly of diatoms 5 (Welker et al., 2002).

\subsection{Experimental design and sampling procedure}

Benthic experiments, conducted from 2009 to 2011, included a simulation of different episodes of anoxia using benthic chambers with each simulation experiment consisting of three separate phases. The first phase, called normoxic, represented conditions that governed the environment at the time of sampling. This phase was followed by the anoxic phase, in which the system inside the benthic chamber slowly became anoxic due to benthic respiration and limited contact with outer environment. The anoxic phase was followed by the recovery phase, in which the benthic chamber was removed and the system was left to recover for at least 7 days. Various durations of anoxia were simulated throughout the project. In 2009, anoxia only 7 days in length was mimicked. In the following year a greater number of experiments were performed, with anoxia lasting 7 days, 1 month, 2 months and 10 months. The recovery phase in all, except the 10 months experiment, lasted 7 days, while in the last phase it lasted 3 months. Samplings of $1 \mathrm{yr}$ anoxia and the $1 \mathrm{yr}$ recovery phase were performed in 2011.

20 In an experiment conducted in 2010, with anoxia onset lasting 7 days, a benthic chamber called Experimental Anoxia Generating Unit (EAGU) were equipped with sensors for dissolved oxygen $\left(\mathrm{O}_{2}\right)$ and sulphide $\left(\mathrm{H}_{2} \mathrm{~S}\right)$ and cameras primarily used for studying the behavior and survival/mortality of benthic infauna since each group of organisms showed different tolerance on changing $\mathrm{O}_{2}$ levels (Reider et al., 2013; Grego et al., 2013a,b; DeTroch et al., 2013; Langlet et al., 2013a,b). The other chambers used were simpler lacking sensors and cameras. They were however designed with special rubber-closed openings used for sample manipulations inside the chamber.

BGD

10, 11729-11755, 2013

Diagenesis and benthic fluxes of nutrients and metals

N. Koron et al.

Title Page

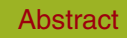

Introduction

Conclusions References

Tables Figures

14 $\rightarrow 1$

4

Back

Close

Printer-friendly Version

Interactive Discussion 
All benthic chamber deployments and sediment core samplings were performed by SCUBA divers after careful and thorough planning of correct positioning of all utensils. Firstly, before the deployment of chambers, 4 cores (normoxic) were sampled using Plexiglass tubes ( $6 \mathrm{~cm}$ i.d., $12 \mathrm{~cm}$ length) and sealed with rubber stoppers underwater. 5 The chambers were pushed approximately $2 \mathrm{~cm}$ into the sediment and carefully sealed to avoid any leakage of ambient water into or experimental water out of the chambers. In the experiment using EAGU, $\mathrm{O}_{2}$ and $\mathrm{H}_{2} \mathrm{~S}$ sensors were used to monitor the evolution of anoxia inside the chamber (Riedel et al., 2013). After the elapsed time set by the experiment outline SCUBA divers again performed core sampling. After sampling, the 10 benthic chamber was carefully removed to avoid any further disturbance of the sediment. The area previously covered by the benthic chamber and anoxic water column became exposed to ambient seawater and the recovery period began. The sampling of the "recovery" sediments was performed after 7 days, following same sampling protocol as before. The sampling procedure was the same in every experiment, except with 2 months anoxia, which lacked the recovery phase. Recovery cores of 7 days and 1 month anoxia experiment were sampled after a 7 day period, whereas in the $1 \mathrm{yr}$ experiment they were collected after 3 months period.

After each campaign, all samples were carefully transported to the lab where the cores were extruded and sectioned into $0.5 \mathrm{~cm}$ thick slices for the upper $2 \mathrm{~cm}$, and $1 \mathrm{~cm}$ slices for next $5 \mathrm{~cm}$. All core sample manipulations, including pore water, were performed in an $\mathrm{N}_{2}$-filled glove bag or box. Core slices were put into sterile $50 \mathrm{~mL}$ centrifuge tubes (Corning Inc.) to allow the pore water extraction. This was performed by centrifugation at $3500 \mathrm{rpm}$ for $20 \mathrm{~min}$ at in situ temperature measured at the sea bottom at the time of sampling. Pore waters from matching depths were filtered through $0.2 \mu \mathrm{m}$ Millipore-HA filters in an inert atmosphere and combined three or four cores to obtain enough sample for all required analyses. Where necessary pore waters were acidified and refrigerated until analyses. Sediments devoid of pore waters (solid phase) were kept frozen until analyses.
BGD

10, 11729-11755, 2013

Diagenesis and

benthic fluxes of

nutrients and metals

N. Koron et al.

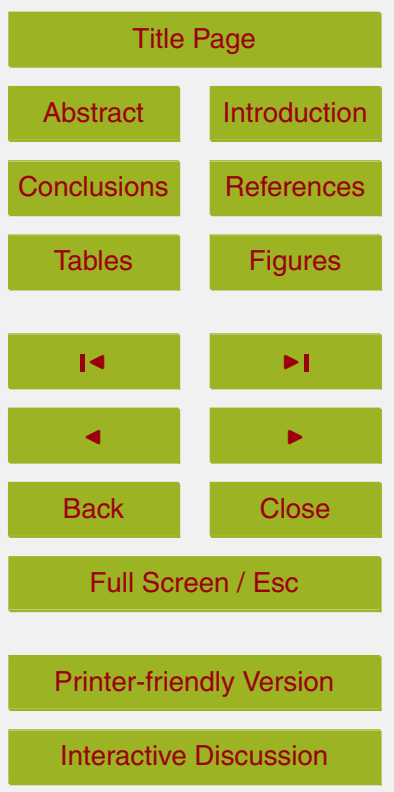




\subsection{Analyses}

\subsubsection{Solid phase}

Sediment samples for $\mathrm{C}_{\text {org }}$ and $\mathrm{N}_{\text {tot }}$ analyses were freeze-dried, ground in an agate mortar and sieved through $200 \mu \mathrm{m}$ mesh to remove coarse shell debris. $\mathrm{C}_{\text {org }}$ was deter5 mined in sediments acidified with $1 \mathrm{M} \mathrm{HCl}$ to quantitatively remove carbonates (Hedges and Stern, 1984), whereas $\mathrm{N}_{\text {tot }}$ was determined in non-acidified samples using a CHN analyzer (Elementar varioMICRO CUBE; Elementar Analysensysteme $\mathrm{GmbH}$, Hanau, Germany). Total $P$ was analyzed by extraction with $1 \mathrm{M} \mathrm{HCl}$ after ignition and $\mathrm{P}_{\text {org }}$ was calculated from the difference in $\mathrm{P}$ contents of $1 \mathrm{M} \mathrm{HCl}$ extracts before and after ig-

nition of the samples (Aspila et al., 1976), whereas $\mathrm{Si}_{\text {biog }}$ was extracted with $\mathrm{Na}_{2} \mathrm{CO}_{3}$ (DeMaster, 1981) and dissolved $\mathrm{Si}(\mathrm{OH})_{4}$ determined colorimetrically (Grasshoff et al., 1999).

A small sediment core was also sampled to determine the porosity of sediments at the experimental site according to Čermelj et al. (1997).

\subsubsection{Pore waters}

Nutrient concentrations in pore waters were determined using standard analytical methods (Grasshoff et al., 1999). Detection limits for nutrients were: $0.5 \mathrm{\mu mol} \mathrm{L}^{-1}$ for $\mathrm{NO}_{3}^{-}+\mathrm{NO}_{2}^{-}, 0.4 \mu \mathrm{molL}^{-1}$ for $\mathrm{NH}_{4}^{+}$and $0.01 \mu \mathrm{molL}^{-1}$ for $\mathrm{PO}_{4}^{3-}$. Concentrations of $\mathrm{Si}$, $\mathrm{Fe}, \mathrm{Mn}, \mathrm{Ca}$ and $\mathrm{Mg}$ in filtered and acidified samples were determined using ICP-OES (Perkin-Elmer Optima 5300 DV). NASS-6 certified reference material was used for quality control. All samples were available in only one replicate, so the reproducibility of the method was determined based on multiple measurements of the standard solutions and reference material, whereas limit of detection and limit of quantification were determined based on three and ten standard deviations of the blank samples measurements, respectively. The method detection limit (MDL) for ICP-OES was cal-

Diagenesis and benthic fluxes of nutrients and metals

N. Koron et al.

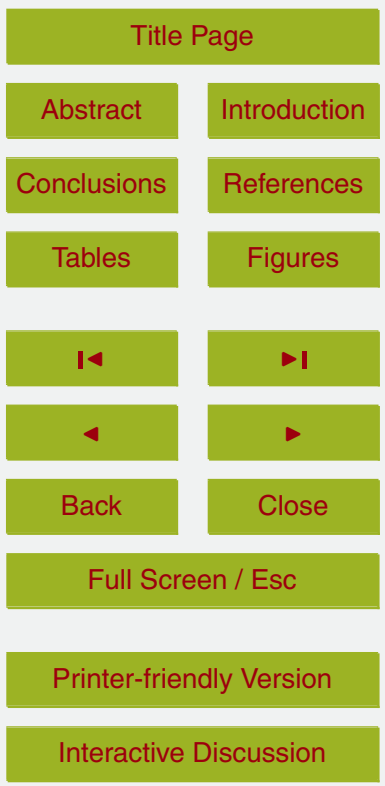


culated based on the t-statistics calculated at two different confidence intervals $(99 \%$ and $95 \%$ ) multiplied by average standard deviation in $\mathrm{mgL}^{-1}$.

\subsubsection{Pore water and benthic flux modelling}

The fluxes of $\mathrm{PO}_{4}^{3-}, \mathrm{NH}_{4}^{+}$, dissolved silicon (dSi), Ca, Mg, Mn and Fe across the sed5 iment-water interface (SWI) were determined using Fick's first law of diffusion and advection (Lerman, 1979):

$F_{z=0}=-\phi D_{\mathrm{s}}\left(\frac{\partial C}{\partial z}\right)+\left.\phi \omega C\right|_{z=0}$

where $F$ is the rate of flux [mol m${ }^{-2} \mathrm{~s}^{-1}$ ], $\Phi$ is sediment porosity, $D_{\mathrm{s}}$ is the effective diffusion coefficient $\left[\mathrm{m}^{-2} \mathrm{yr}^{-1}\right], C / z$ is the concentration gradient across the $S W I\left[\mathrm{~mol} \mathrm{dm}^{-4}\right]$, 10 sedimentation rate $\left[\mathrm{cm} \mathrm{s}^{-1}\right]$. The measured $\Phi$ was 0.55 , while $D_{\mathrm{s}}$ were corrected for temperature and average porosity (Lerman, 1979). $C / z$ was estimated from a profile of concentrations plotted against depth using the diffusion-reaction model for $\mathrm{PO}_{4}^{3-}$, $\mathrm{NH}_{4}^{+}$and $\mathrm{dSi}$, while $\mathrm{Ca}, \mathrm{Mg}, \mathrm{Mn}$ and Fe depth profiles were described by a curve fitting routine of a polynomial function.

15 The diffusion-advection-reaction model included the degradation of OM via firstorder kinetics, equilibrium adsorption from pore water onto sediment particles and dissolution precipitation reactions using the following equation (Lerman, 1979):

$\frac{\partial C}{\partial t}=0=D \frac{\partial^{2} C}{\partial z^{2}}-\omega \frac{\partial C}{\partial z}-k C+J+R_{0} \exp ^{(-\beta z)}$

where $k$ is the reaction rate constant, $J$ is the rate of reaction, $R_{0}$ is the production 20 rate at the SWI [mol dm $\left.{ }^{-3} \mathrm{~s}^{-1}\right]$, is the depth attenuation constant $\left[\mathrm{cm}^{-1}\right]$. The change of $\mathrm{PO}_{4}^{3-}, \mathrm{NH}_{4}^{+}$and $\mathrm{dSi}$ with depth and time in the model was described for every species separately depending on the processes influencing their distribution: decomposition of $\mathrm{OM}$ to $\mathrm{NH}_{4}^{+}$and $\mathrm{PO}_{4}^{3-}$; equilibrium adsorption for $\mathrm{NH}_{4}^{+}, \mathrm{PO}_{4}^{3-}$ following a simple linear

Diagenesis and benthic fluxes of nutrients and metals

N. Koron et al.

Title Page

Abstract Introduction

Conclusions References

Tables Figures

14 $\rightarrow 1$

4

Back

Close

Printer-friendly Version

Interactive Discussion 
isotherm; precipitation of $\mathrm{PO}_{4}^{3-}$ to form authigenic minerals and dissolution of biogenic silica assuming first-order reaction. Thus, the change of nutrient concentrations with depth can be described by the following steady-state differential equations.

For $\mathrm{NH}_{4}^{+}$:

$5 \frac{\partial C}{\partial t}=0=\frac{D_{\mathrm{s}}}{1+K_{\mathrm{N}}} \frac{\partial^{2} C}{\partial z^{2}}-\omega\left(1+K_{\mathrm{N}}\right) \frac{\partial C}{\partial z}+R_{0} \exp ^{(-\beta z)}$

where $K_{\mathrm{N}}$ is the equilibrium adsorption constant for $\mathrm{NH}_{4}^{+}$.

For $\mathrm{PO}_{4}^{3-}$ :

$\frac{\partial C}{\partial t}=0=\frac{D_{\mathrm{s}}}{1+K_{\mathrm{P}}} \frac{\partial^{2} C}{\partial z^{2}}-\omega\left(1+K_{\mathrm{P}}\right) \frac{\partial C}{\partial z}-\frac{k_{\mathrm{m}}\left(C-C_{\mathrm{eq}}\right)}{1+K_{\mathrm{P}}}+R_{0} \exp ^{(-\beta z)}$

where $K_{\mathrm{P}}$ is the equilibrium adsorption constant for $\mathrm{PO}_{4}^{3-}, C_{\text {eq }}$ concentration at satura10 tion with the authigenic precipitate dependent on $\mathrm{T}$ and $k_{\mathrm{m}}$ authigenic mineral precipitation rate constant.

For dSi:

$\frac{\partial C}{\partial t}=0=D_{\mathrm{s}} \frac{\partial^{2} C}{\partial z^{2}}-\omega \frac{\partial C}{\partial z}+k_{\mathrm{m}}\left(C_{\infty}-C\right)$

where $k_{\mathrm{m}}$ is the rate constant for $\mathrm{Si}$ dissolution and $C_{\infty}$ is asymptotic concentration at

at $z=0: C=C_{z=0}$

at $z \rightarrow \infty: C \rightarrow C_{\infty}$ for $\mathrm{NH}_{4}^{+}$and dSi and $C \rightarrow C_{\text {eq }}$ for $\mathrm{PO}_{4}^{3-}$.

The parameters used in the diffusion-advection-reaction model together with the model output data are collected in Table 1.

Diagenesis and

benthic fluxes of

nutrients and metals

N. Koron et al.

Title Page

Abstract

Introduction

Conclusions

References

Tables

Figures

14

$\rightarrow 1$

4

Back

Close

Full Screen / Esc

Printer-friendly Version

Interactive Discussion 


\section{Results}

\subsection{Solid phase}

Results on $\mathrm{C}_{\text {org }}, \mathrm{N}_{\text {tot }} \mathrm{P}_{\text {tot }}, \mathrm{P}_{\text {inorg }}, \mathrm{P}_{\text {org }}$ and $\mathrm{Si}_{\text {biog }}$ results and $\mathrm{C}_{\text {org }} / \mathrm{N}_{\text {tot }}$ and $\mathrm{C}_{\text {org }} / \mathrm{P}_{\text {org }}$ ratios (molar) in the sediment solid phase during anoxia are presented in Fig. 1. Our $5 \mathrm{C}_{\text {org }}, \mathrm{N}_{\text {tot }}, \mathrm{P}_{\text {tot }}, \mathrm{P}_{\text {inorg }}, \mathrm{P}_{\text {org }}$ and $\mathrm{Si}_{\text {biog }}$ results (Fig. 1) from normoxic phase agreed with previously reported values from surficial sediment at this study site (Čermelj et al., 1997; Ogrinc et al., 2005). Little vertical variation of concentrations in all measured parameters was observed except those of $\mathrm{P}_{\text {tot }}$ and $\mathrm{Si}_{\text {biog }}$, which decreased with depth. The $C_{\text {org }} / N_{\text {tot }}$ ratios (molar) ranged from 6 to 12 and $C_{\text {org }} / P_{\text {org }}$ ratios (molar) averaged 10 about 200 both roughly corroborating with the values typical for OM of marine origin (Ogrinc et al., 2005).

During the 1 month and 2 months anoxic phases the $\mathrm{C}_{\text {org }} / \mathrm{N}_{\text {tot }}$ ratios rose to values from 12 to 15 and 11 to 21 , respectively, due to the dropping of $N_{\text {tot }}$ levels. Interestingly, the results of $1 \mathrm{yr}$ anoxia showed relatively high values of $\mathrm{N}_{\text {tot }}$, comparable to those

15 in normoxia, with $C_{\text {org }}$ values being higher than in all short-term experiments. Only changes in the pool of $\mathrm{P}_{\text {org }}$ were observed and the degradation of $\mathrm{P}_{\text {org }}$ was most noticeable in the 2 months anoxia experiment reflecting in higher $\mathrm{C}_{\text {org }} / \mathrm{P}_{\text {org }}$ ratios. $\mathrm{Si}_{\text {biog }}$ levels increased in the 7 days anoxia but were somewhat lower in the longer anoxic conditions. In the recovery phases, the $\mathrm{C}_{\text {org }}$ and $\mathrm{P}_{\text {tot }}$ and $\mathrm{P}_{\text {org }}$ values remained approxi20 mately unchanged in 7 days recovery but were higher in 1 month recovery. Conversely, $\mathrm{N}_{\text {tot }}$ values in both phases were much lower than in normoxia.

\subsection{Nutrients}

Concentrations of $\mathrm{NH}_{4}^{+}$and $\mathrm{PO}_{4}^{3-}$, during normoxia (Fig. 2), were low and relatively constant throughout the whole sediment core, reaching values between 20 and $25115 \mu_{\mathrm{mol} \mathrm{L}}^{-1}$ for $\mathrm{NH}_{4}^{+}$and 2 and $40 \mu \mathrm{molL}^{-1}$ for $\mathrm{PO}_{4}^{3-}$, respectively. Concentrations in overlaying water were lower, around $1 \mu \mathrm{molL}^{-1}$ for $\mathrm{NH}_{4}^{+}$and $0.1 \mu \mathrm{molL}^{-1}$ for $\mathrm{PO}_{4}^{3-}$.

Diagenesis and benthic fluxes of nutrients and metals

N. Koron et al.

\section{Title Page}

\section{Abstract} Introduction

Conclusions References

Tables Figures

14 $\rightarrow$

4

Back

Close

\section{Full Screen / Esc}

Printer-friendly Version

Interactive Discussion 
Pore water $\mathrm{NO}_{3}^{-}$concentrations (not presented) in the normoxic phase ranged from 5 to $35 \mu \mathrm{molL}^{-1}$, whereas the concentration in overlaying water was around $0.1 \mu \mathrm{molL}^{-1}$. The profile of dSi showed lower concentrations at SWI and uniform levels at about $100 \mathrm{~mol} \mathrm{~L}^{-1}$ at all analyzed depths. Normoxic pore water profiles are comparable to 5 those previously reported for the same sampling point (Čermelj et al., 1997; Ogrinc and Faganeli, 2006; Faganeli and Ogrinc, 2009).

Pore water profiles of $\mathrm{NH}_{4}^{+}, \mathrm{PO}_{4}^{3-}$ and dSi during anoxia are presented in Fig. 2. Concentrations of $\mathrm{NH}_{4}^{+}$in the 7 days anoxia experiment were much higher compared to normoxic concentrations (Fig. 2) and ranged from 100 to $200 \mathrm{mmol} \mathrm{L}^{-1}$ showing two 10 distinct peaks at depths between 1.5 and $2 \mathrm{~cm}$ and between 4 and $5 \mathrm{~cm}$, respectively. In 1 month anoxia, the concentrations of $\mathrm{NH}_{4}^{+}$were even higher reaching maximum values of $700 \mathrm{mmol} \mathrm{L}^{-1}$. There was a noticeable increase in concentrations at the depths between 0.5 and $4 \mathrm{~cm}$. In the 2 months and $1 \mathrm{yr}$ anoxia experiment, the concentrations of $\mathrm{NH}_{4}^{+}$dropped and stabilized around $300 \mu \mathrm{mol} \mathrm{L}^{-1}$ and $200 \mu \mathrm{mol} \mathrm{L}^{-1}$, respectively. Con15 centrations of $\mathrm{NO}_{3}^{-}$(not presented) in the 7 days and 1 month anoxia experiments did not change much and were comparable to those in normoxic conditions, ranging from 10 to $40 \mathrm{umol} \mathrm{L}^{-1}$, with peaks overlapping those of $\mathrm{NH}_{4}^{+}$profiles. In the 2 months and $1 \mathrm{yr}$ anoxia experiments, its concentrations rose reaching values up to $100 \mathrm{mmol} \mathrm{L}^{-1}$. The 7 days anoxia $\mathrm{PO}_{4}^{3-}$ profile was similar to $\mathrm{NH}_{4}^{+}$profile. Concentrations rose only 20 in two active layers reaching values of 20 and $40 \mu \mathrm{molL}^{-1}$, respectively. In the $\mathrm{PO}_{4}^{3-}$ depth profiles in the 1 month, 2 months and $1 \mathrm{yr}$ anoxia experiments, the concentrations remained nearly constant throughout the sediment cores. Concentrations ranged from 0.5 to $9 \mu \mathrm{mol} \mathrm{L}^{-1}$, and therefore, did not exceed the values observed in the normoxia or 7 days anoxia experiments. Concentrations of dSi during all anoxia experiments (Fig. 2) 25 increased to levels $>200 \mu \mathrm{molL}^{-1}$. High pore water dSi levels, around $150 \mu \mathrm{mol} \mathrm{L}-1$, also remained during reoxidation phases. Observed irregular ("disrupted") depth profiles of $\mathrm{NH}_{4}^{+}$after 1 month recovery and $\mathrm{PO}_{4}^{3-}$ and $\mathrm{dSi}$ observed after $1 \mathrm{yr}$ of recovery indicate the importance of enhanced bioturbation.
BGD

10, 11729-11755, 2013

Diagenesis and

benthic fluxes of

nutrients and metals

N. Koron et al.

Title Page

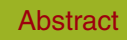

Introduction

Conclusions

Tables

References

Figures

14

- I

4

Back

Close

Printer-friendly Version

Interactive Discussion 


\subsection{Metals}

Vertical pore water profiles of $\mathrm{Ca}$ and $\mathrm{Mg}$ concentrations (Fig. 3) showed lower values in anoxic phases, particularly for Mg during 7 days and 1 month anoxia. In 1 month and $1 \mathrm{yr}$ recovery experiments, pore water $\mathrm{Ca}$ concentrations increased to higher val5 ues than observed in normoxia while Mg concentrations reached levels approximately those encountered in normoxia. Changing of dissolved $\mathrm{Fe}$ and $\mathrm{Mn}(\mathrm{Fe}(\mathrm{II})$ and $\mathrm{Mn}(\mathrm{II}))$ concentrations during anoxia experiments are shown in Fig. 3. In 7 days anoxia, there was a notable increase of $\mathrm{Fe}$ and $\mathrm{Mn}$ concentrations in pore waters compared to values under normoxic conditions. Concentrations increased from values of less than

$105 \mu \mathrm{molL}^{-1}$ for Fe and $35 \mu \mathrm{mol} \mathrm{L}^{-1}$ for $\mathrm{Mn}$, to $35 \mu \mathrm{molL}^{-1}$ for Fe and $110 \mu \mathrm{molL}^{-1}$ for Mn. Two distinct vertical peaks can be seen, one at depth of $0-0.5 \mathrm{~cm}$ and other at 2-4 cm. In the 1 month, 2 months and $1 \mathrm{yr}$ anoxia experiments, the concentrations of Fe were notably lower compared to 7 days anoxia, but still higher than in normoxia. Peaks of increased Fe(II) release into pore waters remain noticeable. Mn profiles in the 157 days and $1 \mathrm{yr}$ anoxia experiments were almost identical to profiles of Fe. Profiles of Mn from 1 month and 2 months anoxia experiments did not show any concentration changes throughout the sediment core. However, the concentrations of dissolved Mn in prolonged anoxia dropped from 150 to $5 \mu \mathrm{molL}^{-1}$.

\subsection{Model calculation and fluxes}

20 The comparison between depth profiles of model calculated and measured $\mathrm{NH}_{4}^{+}, \mathrm{PO}_{4}^{3-}$ and dSi concentrations are presented in Fig. 2. The diagenetic model gave quite a good description of the distribution of nutrients in pore water of 1 month and $1 \mathrm{yr}$ anoxia and 1 month recovery experiments, however, the $1 \mathrm{yr}$ recovery experiment conditions were not reproduced well, since no clear pattern in the measured distribution of nutrient concentrations was observed probably due to enhanced bioturbation. Furthermore, it was also observed that the depth attenuation coefficient increased with the increasing time of the anoxic condition present for both $\mathrm{NH}_{4}^{+}$and $\mathrm{PO}_{4}^{3-}$ from 2.0 to 6.3 and from

Diagenesis and benthic fluxes of nutrients and metals

N. Koron et al.

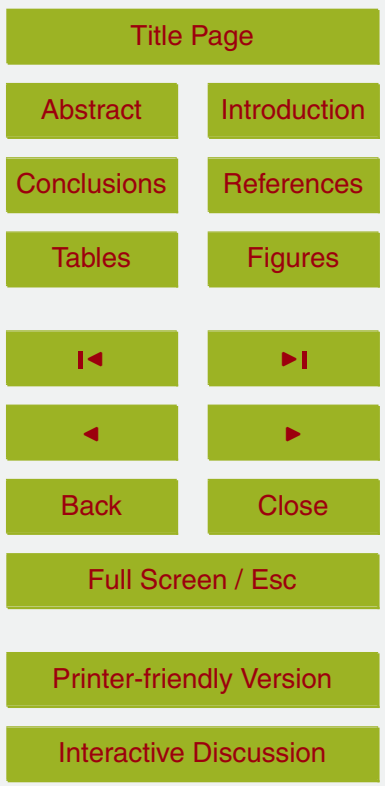


1.6 to 3.8 , respectively. These data show a more pronounced release of both nutrients due to more intense remineralization processes.

Based on the diagenetic models, the diffusive fluxes were calculated and the data are presented in Table 2. The calculated $\mathrm{NH}_{4}^{+}$benthic fluxes ranged from -34 to $5513 \mu \mathrm{molm}^{-2}$ day $^{-1}$ and those of $\mathrm{PO}_{4}^{3-}$ from 1.3 to $13.8 \mu \mathrm{molm}^{-2}$ day $^{-1}$. The highest $\mathrm{NH}_{4}^{+}$efflux was observed after one month of anoxia. On the other hand, the influx of $\mathrm{NH}_{4}^{+}$into sediments was observed after one year of recovery. The dSi fluxes ranged from -140 to $286 \mu \mathrm{molm}^{-2}$ day $^{-1}$. Fe and $\mathrm{Mn}$ exhibited the highest effluxes in 7 days and 1 month anoxia reaching values of 16.6 and $20.1 \mu \mathrm{molm}^{-2}$ day $^{-1}$, respectively. In 10 these experiments, the influx of $\mathrm{Ca}$ into sediment was mainly observed ranging from -10 to $-700 \mathrm{mmolm}^{-2}$ day $^{-1}$ except after 7 days and 1 month recovery. Similar dynamics was found for $\mathrm{Mg}$.

\section{Discussion}

Our study documents the sequential biogeochemical changes occurring during the OM degradation and nutrient regeneration in relatively OM poor coastal surface sediments of the Gulf of Trieste under various redox conditions: normoxic, anoxic and reoxic. It can be seen that the longer the span of anoxia the less pronounced is the rise of concentrations of $\mathrm{NH}_{4}^{+}$and $\mathrm{PO}_{4}^{3-}$ in pore waters. The majority of $\mathrm{NH}_{4}^{+}$and $\mathrm{PO}_{4}^{3-}$ regeneration in anoxic marine environments likely results from hydrolytic and/or fermentative processes that produce low molecular weight molecules from complex sedimentary OM (Burdige, 2002). The utilization of these compounds by sulphate reducing bacteria then results in the complete mineralization of sedimentary OM (Burdige, 2002). Consequently, the sedimentary $C_{\text {org }} / N_{\text {org }}$ ratios and $C_{\text {org }} / P_{\text {org }}$ ratios generally increase with depth in surface coastal marine and estuarine sediments (Hedges and Keil, 1995). This is usually considered as an indication of preferential mineralization of organic nitrogen and phosphorus in sediments and that the more labile fractions have lower $\mathrm{C}_{\text {org }} / \mathrm{N}_{\text {org }}$
BGD

10, 11729-11755, 2013

Diagenesis and

benthic fluxes of

nutrients and metals

N. Koron et al.

Title Page

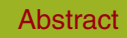

Introduction

Conclusions

References

Tables

Figures

14

$\rightarrow 1$

4

Back

Close

Full Screen / Esc

Printer-friendly Version

Interactive Discussion 
and $\mathrm{C}_{\text {org }} / \mathrm{P}_{\text {org }}$ ratios than the bulk sedimentary OM (Hedges and Keil, 1995; Ingall and Jahnke, 1997). In anoxic conditions, higher pore water $\mathrm{NH}_{4}^{+}$and $\mathrm{PO}_{4}^{3-}$ levels can be also related with the higher density of decaying infaunal organisms providing additional easily degradable "fresh" OM to microbes (Riedel et al., 2013). It was demonstrated, 5 using ${ }^{15} \mathrm{~N}$ incubations, that in the deep Skagerrak sediments the pore water $\mathrm{NH}_{4}^{+}$is the main end product of anoxic $\mathrm{N}$ mineralization (Thamdrup and Dalsgaard, 2000). A build-up of $\mathrm{NH}_{4}^{+}$in pore waters can also be a consequence of other processes in the $\mathrm{N}$ cycle, which can be important in anoxic environments and can simultaneously proceed in microniches. One of them is dissimilatory nitrate reduction to ammonium

RA) (Gardner et al., 2006) which can supersede respiratory denitrification as a process of $\mathrm{NO}_{3}^{-}$removal from the system, when labile organic matter is more available, redox potential and ambient $\mathrm{NO}_{3}^{-}$concentrations are low, and when $\mathrm{H}_{2} \mathrm{~S}$ production is high (Canfield et al., 2005). The $\mathrm{NO}_{3}^{-}$behaviour in sediments of the Gulf of Trieste was somewhat unusual since it was expected to decrease in anoxic pore waters due 15 to denitrification, which rapidly removes $\mathrm{NO}_{3}^{-}$. Results of the 2 months anoxia experiment indicated a possible breach in anoxia, since increased concentrations of $\mathrm{NO}_{3}^{-}$ were seen at two separate depths suggesting that there was an active sediment reworking (outside chamber) and laterally pumping of overlying oxygenated water into deeper layers of chamber sediment (Čermelj et al., 1997). Anamox (anaerobic ammonium oxidation), another important nitrogen process, might be running simultaneously (Dalsgaard et al., 2005) and might explain the increased values of $\mathrm{NO}_{3}^{-}$in anoxic conditions, which is probably formed as a byproduct in $\mathrm{CO}_{2}$ reduction, especially in the 2 months and $1 \mathrm{yr}$ anoxia experiments (van de Graaf et al., 1997). Within the current knowledge of $\mathrm{N}$ cycling in marine sediments, it is suggested that in environments with relatively high $\mathrm{C}_{\text {org }}$ concentrations and high free $\mathrm{H}_{2} \mathrm{~S}$ concentrations, respiratory denitrification is suppressed (because of enzyme inhibition), therefore making DNRA and anammox more important processes for $\mathrm{N}$ recycling (Burgin and Hamilton, 2007). Bottom water hypoxia and anoxia typically lead to increased regeneration of $P$ from sediments and thus increased recycling of $P$ in the system (Conley et al., 2009). Significant

BGD

$10,11729-11755,2013$

Diagenesis and benthic fluxes of nutrients and metals

N. Koron et al.

Title Page

Abstract Introduction

Conclusions

Tables References Figures

14 $\rightarrow 1$

4

Back

Close

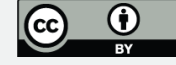


amount of $\mathrm{P}$ is released from Fe-(oxy)hydroxides upon transition from oxic to anoxic conditions (Ogrinc and Faganeli, 2006; Faganeli and Ogrinc, 2009). Enhanced microbial and chemical dissolution of $\mathrm{Si}_{\text {biog }}$ (opal) proceeded in anoxic conditions (Canfield et al., 2005; Belias et al., 2007) and remained high in recovery phases.

5 Distribution of $\mathrm{Mn}, \mathrm{Fe}, \mathrm{Ca}$ and $\mathrm{Mg}$ in pore waters (Fig. 3) further support the thesis of an active microbial metabolism in sediments. Results of Fe and $\mathrm{Mn}$ in the 7 days anoxia experiment show an enhanced release of these species to the water column indicating an active $\mathrm{Fe}$ and $\mathrm{Mn}$ reduction/respiration in these layers. The results clearly show $\mathrm{Fe}$ and $\mathrm{Mn}$ reduction processes since the concentrations of dissolved species notably 10 rise. When the system is subjected to prolonged anoxic conditions, the importance of $\mathrm{Fe}$ and $\mathrm{Mn}$ reduction from our set of results (Fig. 3) becomes less evident. These processes are energetically more favourable than sulphate reduction (Froelich et al., 1979) and even though the DET results (Metzger et al., 2013) indicate that sulphate reduction is the preferential anaerobic microbial process in early diagenesis in these coastal sediments, $\mathrm{Fe}$ and $\mathrm{Mn}$ reduction can proceed in some microniches. DET results of $\mathrm{SO}_{4}^{2-}$ concentrations during anoxia experiments (Metzger et al., 2013) also clearly showed the migration of redox layers towards SWI and the increasing importance of sulphate reduction over prolonged anoxia spans. The prevalence of sulphate reduction, as a major anaerobic path of early OM diagenesis in coastal marine sediments, over other electron acceptors, was demonstrated for surface sediments in the Gulf of Trieste (Hines et al., 1997). In anoxic conditions, Ca and Mg pore water concentrations indicate lower carbonate dissolution or even carbonate precipitation as previously postulated for surface anoxic sediments of the Gulf of Trieste (Čermelj et al., 2001; Ogrinc et al., 2003).

25 In the recovery experiments, the normoxic biogeochemical conditions of metals were almost completely restored in 7 days even though this was not completely true for higher organisms (infauna). Reoxygenation of previously anoxic sediments promotes OM remineralization (Hulthe et al., 1998; Bastviken et al., 2004). Unfortunately, data on pore water nutrient concentrations in 7 days recovery period following an $\mathrm{O}_{2}$ water
BGD

10, 11729-11755, 2013

Diagenesis and

benthic fluxes of

nutrients and metals

N. Koron et al.

Title Page

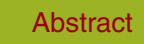

Introduction

Conclusions

Tables

References

Figures

14

I

4

Back

Close

Printer-friendly Version

Interactive Discussion 
penetration are missing. We observed, however, a peak of $\mathrm{NO}_{3}^{-}$at a depth of $4-5 \mathrm{~cm}$ in the 7 days reoxygenation phase, which may be a consequence of enhanced bioturbation also clearly evident in $\mathrm{NH}_{4}^{+}$, dSi and Fe pore water profiles especially in the $1 \mathrm{yr}$ recovery experiment. Nitrification was a likely cause of relative $\mathrm{NH}_{4}^{+}$depletion. When oxic conditions reappears $\mathrm{P}$ precipitates quickly as authigenic carbonate fluorapatite, $\mathrm{FePO}_{4}$ or it is adsorbed onto Fe-hydroxides (Ogrinc and Faganeli, 2006), most probably onto goethite having a large sorption capacity for phosphate (Arčon et al., 1999). This is confirmed by the rapid decrease of pore water Fe concentrations after 7 days of recovery precipitating as Fe-oxyhydroxides. Increased pore water Ca concentrations in 10 longer recovery experiments reflect enhanced carbonate dissolution in oxic conditions (Ogrinc et al., 2003).

The differences between N, P and Si cycling in oxic, anoxic and reoxic phases can be estimated by comparing their benthic diffusive fluxes and burial. The amount of $\mathrm{N}_{\text {tot }}, \mathrm{P}_{\text {tot. }}$ and $\mathrm{Si}_{\text {biog }}$ buried in sediment was calculated from the sedimentation rate $(\omega)$ 15 and the concentration $(C)$ of sedimentary $N_{\text {tot }}, P_{\text {tot }}$ and $S i_{\text {biog }}$ in the deepest measured sediment layer (approximately $7 \mathrm{~cm}$ ), since they are nearly constant and less affected by bioturbation, using the following equation:

Burial $=\omega C \rho(1-\Phi)$

$\rho$ is the dry density $\left(2.5 \mathrm{~g} \mathrm{~cm}^{-3}\right.$; Ogorelec et al., 1991$), \Phi$ porosity $(0.55)$ and $20 \omega$ sedimentation rate $\left(1.2 \mathrm{~mm} \mathrm{yr}^{-1}\right)$ estimated from ${ }^{210} \mathrm{~Pb}$ measurements (Faganeli et al., 1991). Burial fluxes of $\mathrm{N}_{\text {tot }}, \mathrm{P}_{\text {tot. }}$ and $\mathrm{Si}_{\text {biog }}$ amounted to 170,30 and $6800 \mu \mathrm{mol} \mathrm{m}^{-2}$ day $^{-1}$, respectively. Comparison between benthic fluxes (Table 2) and burial revealed that the intensive recycling of dissolved inorganic $\mathrm{N}$ at the SWI is enhanced in anoxic conditions while $\mathrm{P}$ benthic fluxes appear extremely low even in anoxic phases despite the evident increase of $\mathrm{Fe}$ (and $\mathrm{Mn}$ ) fluxes particularly in early anoxic stages (Table 2). This suggests an important role of $\mathrm{P}$ precipitation as authigenic carbonate fluoroapatite (Ingall and Jahnke, 1997). Si recycling appears much less intensive compared to burial flux in all redox phases indicating rather low $\mathrm{Si}_{\text {biog }}$ solubility. 11744
BGD

$10,11729-11755,2013$

Diagenesis and

benthic fluxes of

nutrients and metals

N. Koron et al.

Title Page

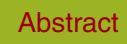

Introduction

Conclusions

References

Tables

Figures

14

$\rightarrow 1$

4

Back

Close

Full Screen / Esc

Printer-friendly Version

Interactive Discussion 
Conversely, carbonates seem more reactive showing precipitation ( $\mathrm{Ca}$ and $\mathrm{Mg}$ influx) in anoxic conditions. The comparison between diffusive and laboratory incubated benthic fluxes in oxic and anoxic conditions, reported previously for the same sampling point (Faganeli and Ogrinc, 2009), reveals lower values of $\mathrm{NH}_{4}^{+}$and $\mathrm{PO}_{4}^{3-}$ diffusive fluxes for 5 both conditions which can be attributed to the presence of bioturbation, not included in modelling approach, and differences in experimental approach. Benthic fluxes integrate the processes in the whole sedimentary column while diffusive fluxes consider changes at SWI.

\section{Conclusions}

1. The study of sequential nutrient regeneration and OM degradation in surface sedprimarily focused into variations of pore water composition. $\mathrm{NH}_{4}^{+}$and $\mathrm{PO}_{4}^{3-}$ regeneration was more intensive in anoxic phases but prolonged span of anoxia reduced their increase. Consequently, the solid phase $\mathrm{N}_{\text {tot }}$ and $\mathrm{P}_{\text {org }}$ contents decreased increasing $\mathrm{C}_{\text {org }} / \mathrm{N}_{\text {tot }}$ and $\mathrm{C}_{\text {org }} / \mathrm{P}_{\text {org }}$ ratios. Higher pore water $\mathrm{NH}_{4}^{+}$levels were presumably also a consequence of dissimilatory nitrate reduction to $\mathrm{NH}_{4}^{+}$ that is a concurrent process of denitrification in removing $\mathrm{NO}_{3}^{-}$. The presence of $\mathrm{NO}_{3}^{-}$in anoxic phases can be explained by the presence of anammox and laterally pumping of oxygenated water by benthic infauna. Enhanced dissolution of $\mathrm{Si}_{\text {biog }}$ was also observed in anoxic phases. Anoxic phases were characterized by higher pore water $\mathrm{Fe}$ and $\mathrm{Mn}$ concentrations as a result of reduction/respiration which is prevailed by sulphate reduction. The decreased pore water $\mathrm{Ca}$ and $\mathrm{Mg}$ concentrations compared to normoxia indicated carbonate precipitation.

2. Reoxygenation was characterized by enhanced bioturbation. Nitrification caused $\mathrm{NH}_{4}^{+}$decrease and $\mathrm{P}$ precipitated quickly as carbonate fluorapatite, $\mathrm{FePO}_{4}$ and it iments of the Gulf of Trieste under normoxic, anoxic and reoxic conditions were
BGD

10, 11729-11755, 2013

Diagenesis and

benthic fluxes of

nutrients and metals

N. Koron et al.

Title Page

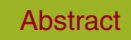

Introduction

Conclusions

References

Tables

Figures

14

$\rightarrow 1$

4

Back

Close

Full Screen / Esc

Printer-friendly Version

Interactive Discussion 
is adsorbed onto Fe-hydroxides since Fe (and $\mathrm{Mn}$ ) reoxidized quickly. Increased Ca levels suggested enhanced carbonate dissolution.

3. Diffusive benthic fluxes at the SWI, calculated from pore water modelling using diffusion-reaction model, showed high anoxic $\mathrm{NH}_{4}^{+}$effluxes and $\mathrm{Ca}$ (and $\mathrm{Mg}$ ) influxes according to described processes. $\mathrm{PO}_{4}^{3-}$ fluxes were very low despite pronounced anoxic $\mathrm{Fe}$ and $\mathrm{Mn}$ effluxes. High $\mathrm{NH}_{4}^{+} / \mathrm{PO}_{4}^{3-}$ flux ratios in anoxic and reoxic phases suggest an excess of $\mathrm{N}$ in the benthos. Nutrient budgets at the SWI, i.e. comparison between diffusive benthic and burial fluxes, showed intensive anoxic recycling of inorganic $\mathrm{N}$ but low $\mathrm{P}$ and $\mathrm{Si}$ recycling in all redox phases.

10 Acknowledgements. The research was conducted in the framework of the Austrian Science Fund (FWF) project P21542-B17 entitled "Low dissolved oxygen events in the Northern Adriatic: in situ experimental insights into benthic responses before, during and post-anoxia". This part of the research was also financially supported by the Research Programme P1-0143 and the Young Researcher Programme of the Slovenian Research Agency (ARRS). We thank M.

15 Stachowitsch, M. Zuschin, I. Gallmetzer and A. Haselmair for technical and diving support.

\section{References}

Aller, R. C.: Topics in geobiology: the effects of macrobenthos on chemical properties of marine sediment and overlying water, in: Animal-Sediment Relations: The Biogenic Alteration of Sediments, edited by: McCall, P. L. and Tevesz, M. J. S., Plenum Press, New York, 53-102, 1982.

Aller, R. C. and Yingst, J. Y.: Relationship between microbial distribution and the anaerobic composition of organic matter in surface sediments of Long Island Sound, Mar. Biol., 56, 29-42, 1988.

Arčon, I., Ogrinc, N., Kodre, A., and Faganeli, J.: EXAFS and XANES characterization of sedimentary iron in the Gulf of Trieste (N Adriatic), J. Synchrotron. Radiat., 6, 659-660, 1999.

Aspila, K. I., Agemian, H., and Chau, H. S. Y.: A semi-automated method for the determination of inorganic, organic and total phosphate in sediments, Analyst, 101, 187-197, 1976.

Diagenesis and

benthic fluxes of

nutrients and metals

N. Koron et al.

Title Page

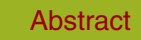

Conclusions

Tables

14

4

Back

Full Screen / Esc

Printer-friendly Version

Interactive Discussion 
Bastviken, D., Persson, L., Odham, G., and Tranvik, L.: Degradation of dissolved organic matter in oxic and anoxic lake water, Limnol. Oceanogr., 49, 109-116, 2004.

Bellias, C., Dassenakis, M., and Scoullos, M.: Study of N, P and Si fluxes between fish farm and sediment and seawater, results of simulation experiments employing a benthic chamber

5 under various redox conditions, Mar. Chem., 103, 266-275, 2007.

Berner, R. A.: Early Digenesis, Princeton University Press, Princeton, 241 pp., 1980.

Brunet, R. C. and Garcia-Gil, L. J.: Sulfide-induced dissimilatory nitrate reduction to ammonia in anaerobic freshwater sediments, FEMS Microbiol. Ecol., 21, 131-138, 1996.

Burdige, D. J.: Sediment pore waters, in: Biogeochemistry of Marine Dissolved Organic Matter, edited by: Hansell, C., and Carlson, C., Academic, New York, 611-664, 2002.

Burgin, A. J. and Hamilton, S. K.: Have we overemphasized the role of denitrification in aquatic ecosystems? A review of nitrate removal pathways, Front. Ecol. Environ., 5, 89-96, 2007.

Canfield, D. E., Thamdrup, B., and Krstensen, E.: Aquatic Geomicrobiology, Advances in Marine Biology, vol. 48, Elsevier, Amsterdam, 640 pp., 2005.

Conley, D. J., Bjorck, S., Destouni, G., Gustafsson, B. G., Hietanen, S., Kortekaas, M., Kuosa, H., Markus Meier, H. E., Muller-Karulis, B., Nordberg, K., Norkko, A., Nurmberd, G., Pitkanen, H., Rabalais, N. N., Rosemberg, R., Savchuk, O. P., Slomp, C. P., Voss, M., Wulff, F., and Zillen, L.: Hypoxia-related processes in the Baltic Sea, Environ. Sci. Technol., 43, 3412-3420, 2009.

20

Čermelj, B., Bertuzzi, A., and Faganeli, J.: Modelling of pore water nutrient distribution and benthic fluxes in shallow coastal waters (Gulf of Trieste, northern Adriatic), Water Air Soil Poll., 99, 435-444, 1997.

Čermelj, B., Ogrinc, N., and Faganeli, J.: Anoxic mineralization of biogenic debris in nearshore marine sediments (Gulf of Trieste, northern Adriatic), Sci. Total Environ., 266, 143$25 \quad 152,2001$.

Dalsgaard, T., Thamdrup, B., and Canfield, D. E.: Anaerobic ammonium oxidation (Anammox) in the marine environment, Res. Microbiol., 156, 457-464, 205.

DeMaster, D. J.: The supply and accumulation of silica in the marine environment, Geochim. Cosmochim. Ac., 45, 1715-1732, 1981.

30 De Troch, M., Roelofs, M., Riedel, B., and Grego, M.: Structural and functional responses of harpacticoid copepods to anoxia in the Northern Adriatic: an experimental approach, Biogeosciences, 10, 4259-4272, doi:10.5194/bg-10-4259-2013, 2013.

Diagenesis and

benthic fluxes of

nutrients and metals

N. Koron et al.

Title Page

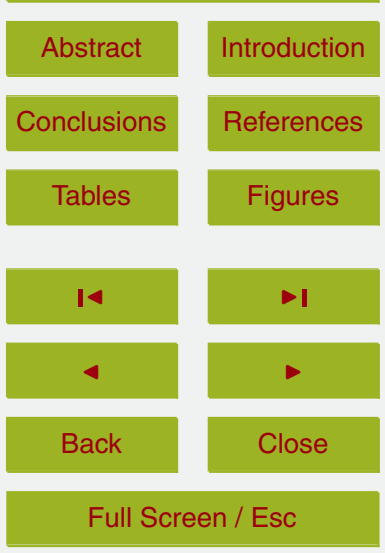

Printer-friendly Version

Interactive Discussion 
Diaz, R. J. and Rosenberg, R.: Spreading dead zones and consequences for marine ecosystems, Science, 321, 926-929, 2008.

Engstrom, P., Dalsgaard, T., Hulth, S., and Aller, R. C.: Anaerobic ammonium oxidation by nitrite (anammox): implications for $\mathrm{N}_{2}$ production in coastal marine sediments, Geochim.

5 Cosmochim. Ac., 69, 2057-2065, 2005.

Faganeli, J., Avčin, A., Fanuko, N., Malej, A., Turk, V., Tusnik, P., Vriser, B., and Vukovič, A.: Bottom layer anoxia in the central part of the Gulf of Trieste in the late summer of 1983, Mar. Pollut. Bull., 16, 75-78, 1985.

Faganeli, J., Planinc, R., Pezdič, J., Smodiš, B., Stegnar, P, and Ogorelec, B.: Marine geology of the Gulf of Trieste (northern Adriatic): geochemical aspects, Mar. Geol., 99, 93-108, 1991.

Faganeli, J. and Ogrinc, N.: Oxic-anoxic transition of benthic fluxes from the coastal marine environment (Gulf of Trieste, northern Adriatic Sea), Mar. Freshwater Res., 60, 700-711, 2009.

Froelich, P. N., Klinkhammer, M. L., Bender, N. A., Luedtke, G. R., Heath, G. R., Cullen, D., 15 Dauphin, P., Hammond, D., Hartman, B., and Maynard, V.: Early oxidation of organic matter in pelagic sediments of the eastern equatorial Atlantic: Suboxic diagenesis, Geochim. Cosmochim. Ac., 43, 1075-1090, 1997.

Gardner, W. S., McCarthy, M. J., An, S., Sobolev, D., Sell, K. S., and Brock, D.: Nitrogen fixation and dissimilatory nitrate reduction to ammonium (DNRA) support nitrogen dynamics in Texas 20 estuaries, Limnol. Oceanogr., 51, 558-568, 2006.

Grasshoff, K., Kremling, K., and Ehrhardt, M.: Methods of Seawater Analysis, 3rd edn., WileyVCH, Weinheim, 632 pp., 1999.

Grego, M., Stachowitsch, M., De Troch, M., and Riedel, B.: Cell Tracker Green labelling vs. Rose Bengal staining: CTG wins by points in distinguishing living from dead anoxia-impacted copepods and nematodes, Biogeosciences, in preparation, 2013

Grego, M., Stachowitsch, M., and De Troch, M.: Meiofauna winners and losers of coastal hypoxia: case study harpacticoid copepods, Biogeosciences, submitted, 2013.

Hedges, J. I. and Keil, R. G.: Sedimentary organic matter preservation: an assessment and speculative synthesis, Mar. Chem., 49, 81-115, 1995.

30 Hedges, J. I. and Stern, J. H.: Carbon and nitrogen determinations of carbonate-containing solids, Limnol. Oceanogr., 29, 195-212, 1984.

Diagenesis and

benthic fluxes of

nutrients and metals

N. Koron et al.

Title Page

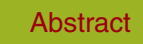

Conclusions

Tables

14

4

Back

Full Screen / Esc

Printer-friendly Version

Interactive Discussion 
Hines, M. E., Faganeli, J., and Planinc, R.: Sedimentary anaerobic microbial biogeochemistry in the Gulf of Trieste, northern Adriatic Sea: influences of bottom water oxygen depletion, Biogeochemistry, 39, 65-86, 1997.

Hulthe, G., Hulth, S., and Hall, P. O. J.: Effect of oxygen on degradation rates of refractory and labile organic matter in continental margin sediments, Geochim. Cosmoschim. Ac., 62, 1319-1328, 1998.

Hunter, W. R., Levin, L. A., Kitazato, H., and Witte, U.: Macrobenthic assemblage structure and organismal stoichiometry control faunal processing of particulate organic carbon and nitrogen in oxygen minimum zone sediments, Biogeosciences, 9, 993-1006, doi:10.5194/bg9-993-2012, 2012.

Ingall, E. and Jahnke, R.: Influence of water-column anoxia the elemental fractionation of carbon and phosphorus during sediment diagenesis, Mar. Geol., 139, 219-229, 1997.

Kemp, M., Faganeli, J., Puškaric, S., Smith, E. M., and Boynton, W. R.: Pelagic-benthic coupling and nutrient cycling, in: Ecosystems at the Land-Sea Margin: Drainage Basin to Coastal Sea, edited by: Malone, T. C., Malej, A., Harding Jr., L. W., Smodlaka, N., and Turner, R. E., American Geophysical Union, Washington DC, USA, 295-339, 1999.

Langlet, D., Baal, C., Geslin, E., Metzger, E., Zuschin, M., Riedel, B., Stachowitsch, M., and Jorissen, F.: Foraminiferal species responses to in situ experimentally induced anoxia in the Adriatic Sea, Biogeosciences, in press, 2013.

20 Langlet, D., Geslin, E., Baal, C., Metzger, E., Zuschin, M., Riedel, B., Stachowitsch, M., and Jorissen, F.: Foraminiferal survival after one year of experimentally induced anoxia, Biogeosciences, published, 2013.

Lerman, A.: Geochemical Processes: Water and Sediment Environments, Wiley, New York, 481 pp., 1979.

Metzger, E., Langlet, D., Viollier, E., Koron, N., Riedel, B., Faganeli, J., Tharaud, M., Geslin, E., Jorissen, F., and Stachowitsch, M.: Artificially induced migration of redox layers in a coastal sediment from the northern Adriatic, Biogeosciences, accepted, 2013.

Mozetič, P., France, J., Kogovšek, T., Talaber, I., and Malej, A.: Plankton trends nd community changes in a coastal sea (northern Adriatic): bottom-up vs. top-down control in relation to 30 environmental drivers, Estuar. Coast. Shelf Science, 115, 138-148, 2012.

Ogorelec, B., Mišič, M., and Faganeli, J.: Marine geology of the Gulf of Trieste (northern Adriatic): sedimentological aspects, Mar. Geol., 99, 79-92, 1991.
BGD

10, 11729-11755, 2013

Diagenesis and

benthic fluxes of

nutrients and metals

N. Koron et al.

Title Page

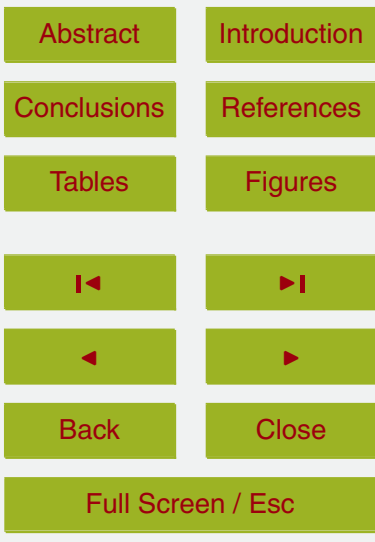

Printer-friendly Version

Interactive Discussion 
Ogrinc, N. and Faganeli, J.: Phosphorus regeneration and burial in near-shore marine sediments (the Gulf of Trieste, northern Adriatic Sea), Estuar. Coast. Shelf S., 67, 579-588, 2006.

Ogrinc, N., Faganeli, J., and Pezdič, J.: Determination of organic carbon remineralization in 5 near-shore marine sediments (Gulf of Trieste, northern Adriatic) using stable carbon isotopes, Org. Geochem., 34, 681-692, 2003.

Ogrinc, N., Fontolan, G., Faganeli, J., and Covelli, S.: Carbon and nitrogen isotope compositions of organic matter in coastal marine sediments (the Gulf of Trieste, N Adriatic Sea): indicators of sources and preservation, Mar. Chem., 95, 163-181, 2005.

10 Riedel, B., Zuschin, M., Haselmair, A., and Stachowitsch, M.: Oxygen depletion under glass: behavioural responses of benthic macrofauna to induced anoxia in the northern Adriatic, J. Exp. Mar. Biol. Ecol., 367, 17-27, 2008.

Riedel, B., Pados, T., Pretterebner, K., Schiemer, L., Steckbauer, A., Haselmair, A., Zuschin, M., and Stachowitsch, M.: Effect of hypoxia and anoxia on invertebrate behaviour: ecological perspectives from species to community level, Biogeosciences, in review, 2013.

Stachowitsch, M.: Anoxia in the northern Adriatic Sea: rapid death, slow recovery, Geol. Soc. Spec. Publ., 58, 119-129, 1991.

Stachowitsch, M., Riedel, B., Zuschin, M., and Machan, R.: Oxygen depletion and benthic mortalities: the first in situ experimental approach to documenting an elusive phenomenon,

20 Limnol. Oceanogr. Meth., 5, 344-352, 2007.

Thamdrup, B. and Dalsgaard, T.: The fate of ammonium in anoxic manganese oxide-rich marine sediment, Geochim. Cosmochim. Ac., 64, 4157-4164, 2000.

Van de Graaf, A. A., de Brujin, P., Robertson, L. A., Jetten, M. S. M., and Kuenen, J. G.: Methabolic pathway of anaerobic ammonium oxidation on the basis of $\mathrm{N}-15$ studies in a fluidized bed reactor, Microbiology-UK, 143, 2415-2421, 1997.

Welker, C., Sdrigotti, E., Covelli, S., and Faganeli, J.: Microphytobenthos in the Gulf of Trieste (northern Adriatic Sea): relationship with labile sedimentary organic matter and nutrients, Estuar. Coast. Shelf S., 55, 259-273, 2002.
BGD

$10,11729-11755,2013$

Diagenesis and

benthic fluxes of

nutrients and metals

N. Koron et al.

Title Page

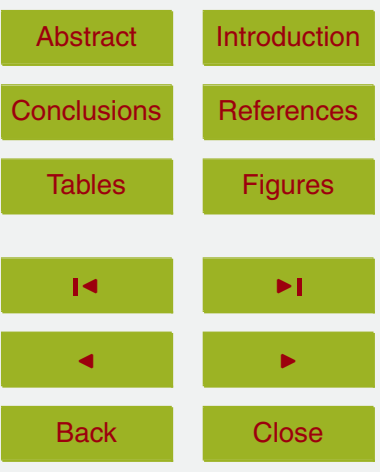

Full Screen / Esc

Printer-friendly Version

Interactive Discussion 
Table 1. Parametres used in the diffusion-advection-reaction model. Values marked with ${ }^{a}$ were measured values, the others were output model data.

\begin{tabular}{|c|c|c|c|}
\hline Parameters & Units & Value & Description \\
\hline $\mathrm{D}_{\mathrm{s}}\left(\mathrm{NH}_{4}^{+}\right)$ & $10^{-6} \mathrm{~cm}^{2} \mathrm{~s}^{-1}$ & $9.06-10.9$ & Sediment diffusion coefficient ${ }^{a}$ \\
\hline $\mathrm{D}_{\mathrm{s}}\left(\mathrm{PO}_{4}^{3-}\right)$ & $10^{-6} \mathrm{~cm}^{2} \mathrm{~s}^{-1}$ & $2.78-3.40$ & Sediment diffusion coefficient ${ }^{\mathrm{a}}$ \\
\hline$D_{s}(d S i)$ & $10^{-6} \mathrm{~cm}^{2} \mathrm{~s}^{-1}$ & $4.54-5.56$ & Sediment diffusion coefficient ${ }^{a}$ \\
\hline$D_{s}(C a)$ & $10^{-6} \mathrm{~cm}^{2} \mathrm{~s}^{-1}$ & $3.72-4.56$ & Sediment diffusion coefficient ${ }^{a}$ \\
\hline $\mathrm{D}_{\mathrm{s}}(\mathrm{Mg})$ & $10^{-6} \mathrm{~cm}^{2} \mathrm{~s}^{-1}$ & $3.17-3.81$ & Sediment diffusion coefficient ${ }^{a}$ \\
\hline $\mathrm{D}_{\mathrm{s}}(\mathrm{Mn})$ & $10^{-6} \mathrm{~cm}^{2} \mathrm{~s}^{-1}$ & $3.05-3.73$ & Sediment diffusion coefficient ${ }^{a}$ \\
\hline $\mathrm{D}_{\mathrm{s}}(\mathrm{Fe})$ & $10^{-6} \mathrm{~cm}^{2} \mathrm{~s}^{-1}$ & $2.76-3.37$ & Sediment diffusion coefficient ${ }^{a}$ \\
\hline$\Omega$ & $\mathrm{Cm} \mathrm{yr}^{-1}$ & 0.15 & Sedimentation rate ${ }^{a}$ \\
\hline$\Phi$ & & $0.49-0.62$ & Porosity in sediments ${ }^{a}$ \\
\hline $\begin{array}{l}\mathrm{k}_{\mathrm{m}} \\
\mathrm{K}_{\mathrm{N}}\end{array}$ & $10^{-7} \mathrm{~s}^{-1}$ & $\begin{array}{l}17-1083 \\
1.3\end{array}$ & $\begin{array}{l}\text { Rate constant for silicate dissolutior } \\
\text { Equilibrium constant for } \mathrm{NH}_{4}^{+}\end{array}$ \\
\hline $\mathrm{K}_{\mathrm{P}}$ & & 2 & Equilibrium constant for $\mathrm{PO}_{4}^{3-}$ \\
\hline$\beta_{\mathrm{N}}$ & $\mathrm{cm}^{-1}$ & $1.81-6.32$ & Attenuation depth constant for $\mathrm{NH}_{4}^{+}$ \\
\hline$\beta_{\mathrm{P}}$ & $\mathrm{cm}^{-1}$ & $0.73-3.88$ & Attenuation depth constant for $\mathrm{PO}_{4}^{3-}$ \\
\hline$C_{z}=0$ & $\mu \mathrm{molL}^{-1}$ & $0.31-1.56$ & Concentration of $\mathrm{NH}_{4}^{+\mathrm{a}}$ \\
\hline$C_{z}=0$ & $\mu \mathrm{mol} \mathrm{L}^{-1}$ & $0.98-55.5$ & Concentration of $\mathrm{PO}_{4}^{3-\mathrm{a}}$ \\
\hline
\end{tabular}

Diagenesis and

benthic fluxes of

nutrients and metals

N. Koron et al.

\section{Title Page}

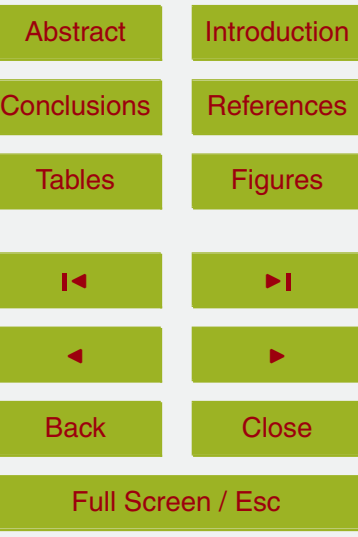

Printer-friendly Version

Interactive Discussion 
Table 2. Diffusive benthic fluxes of nutrients and metals from different experiments calculated from diffusion-advection-reaction model and pore water concentration gradients.

\begin{tabular}{llrrrrrrrr}
\hline Date & Eksperiment & $\begin{array}{c}T \\
{ }^{\circ} \mathrm{C}\end{array}$ & $\begin{array}{c}\mathrm{NH}_{4}^{+} \\
\end{array}$ & $\begin{array}{c}\mathrm{PO}_{4}^{3-} \\
\mu \mathrm{molm}^{-2} \text { day }^{-1}\end{array}$ & $\begin{array}{c}\mathrm{dSi} \\
\mathrm{Mn}\end{array}$ & $\mathrm{Fe}$ & $\begin{array}{r}\mathrm{Ca} \\
\mathrm{mmolm}^{-2} \text { day }^{-1}\end{array}$ \\
\hline 3 Aug 2010 & normoxia & 23.0 & 108 & 13.4 & 36.5 & 3.69 & -0.21 & -0.07 & -0.40 \\
11 Aug 2010 & 7d anoxia & 25.2 & 194 & 13.8 & -140 & 8.17 & 16.6 & -0.19 & -1.09 \\
18 Aug 2010 & 7d recovery & 24.5 & & & 61.5 & 0.45 & 3.14 & 0.07 & 0.07 \\
25 Aug 2010 & 1mo anoxia & 25.5 & 513 & 4.72 & 97.8 & 20.1 & 7.66 & -0.70 & -2.63 \\
22 Sep 2010 & 1mo recovery & 20.5 & 47.9 & 7.51 & 181 & -2.87 & 7.75 & 0.37 & 0.12 \\
23 Sep 2010 & 2mo anoxia & 21.5 & 343 & 7.39 & 78.7 & 5.64 & -0.05 & -0.45 & 0.31 \\
5 Aug 2011 & 1y anoxia & 24.7 & 196 & 1.32 & 286 & 1.87 & 3.17 & -0.35 & -1.05 \\
22 Oct 2011 & 1y recovery & 17.0 & -34.0 & 2.24 & 75.7 & 7.11 & 2.32 & -0.01 & -0.98 \\
\hline
\end{tabular}

Diagenesis and

benthic fluxes of

nutrients and metals

N. Koron et al.

Title Page

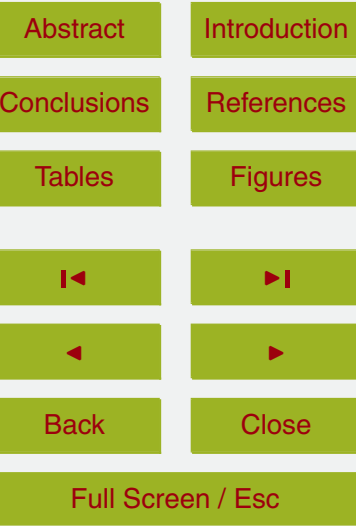

Printer-friendly Version

Interactive Discussion 


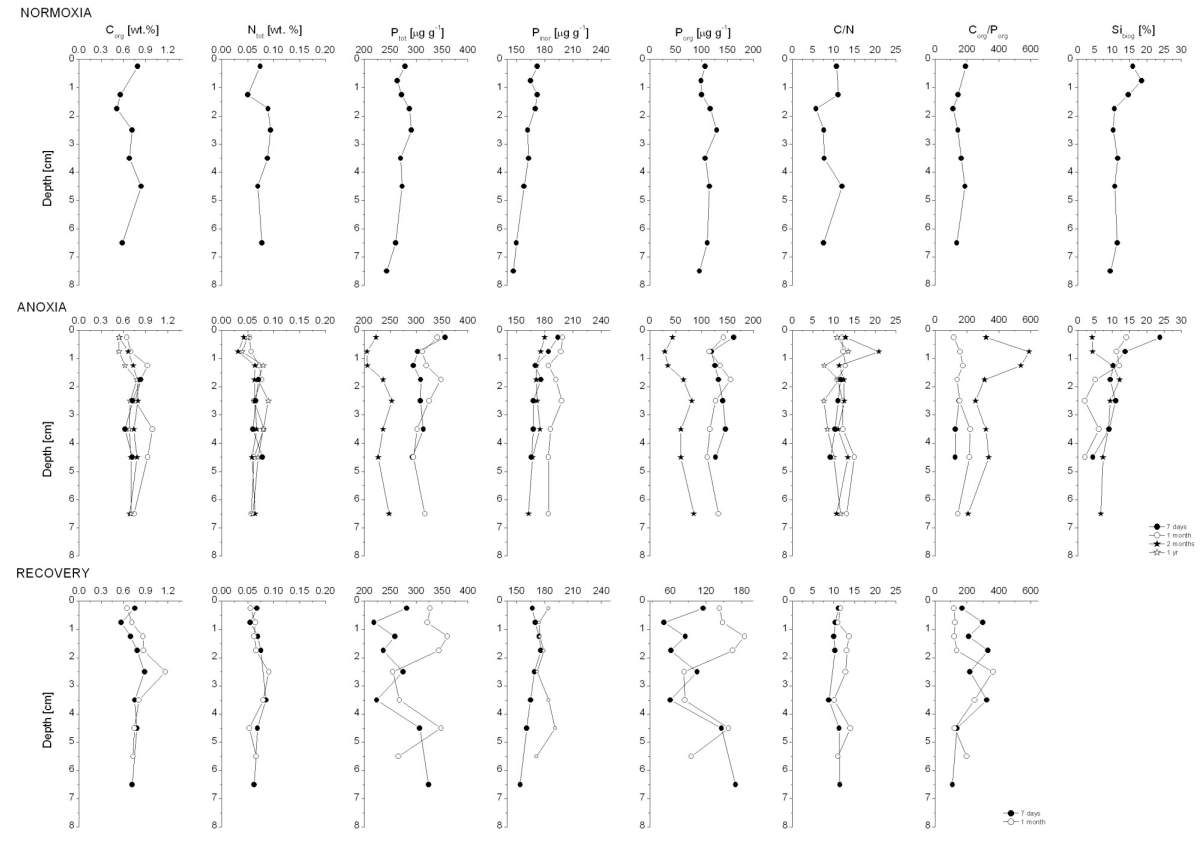

\section{BGD}

$10,11729-11755,2013$

\section{Diagenesis and benthic fluxes of} nutrients and metals

N. Koron et al.

Title Page

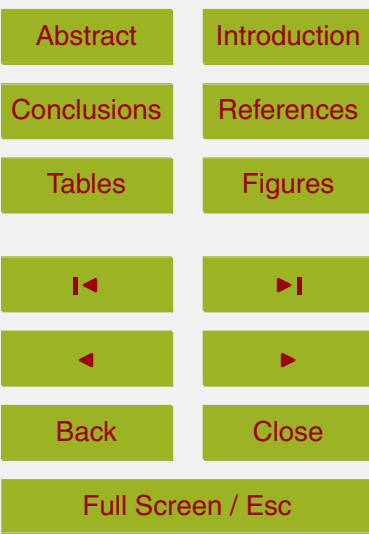

Fig. 1. Distribution of $C_{\text {org }}, N_{\text {tot }}, P_{\text {tot }}, P_{\text {inorg }}, P_{\text {org }}, C / N$ and $C_{\text {org }} / P_{\text {org }}$ ratios together with $\mathrm{Si}_{\text {biog }}$ in sediment solid phase during normoxic-anoxic-reoxic experiments performed in the Gulf of Trieste.

Printer-friendly Version

Interactive Discussion 

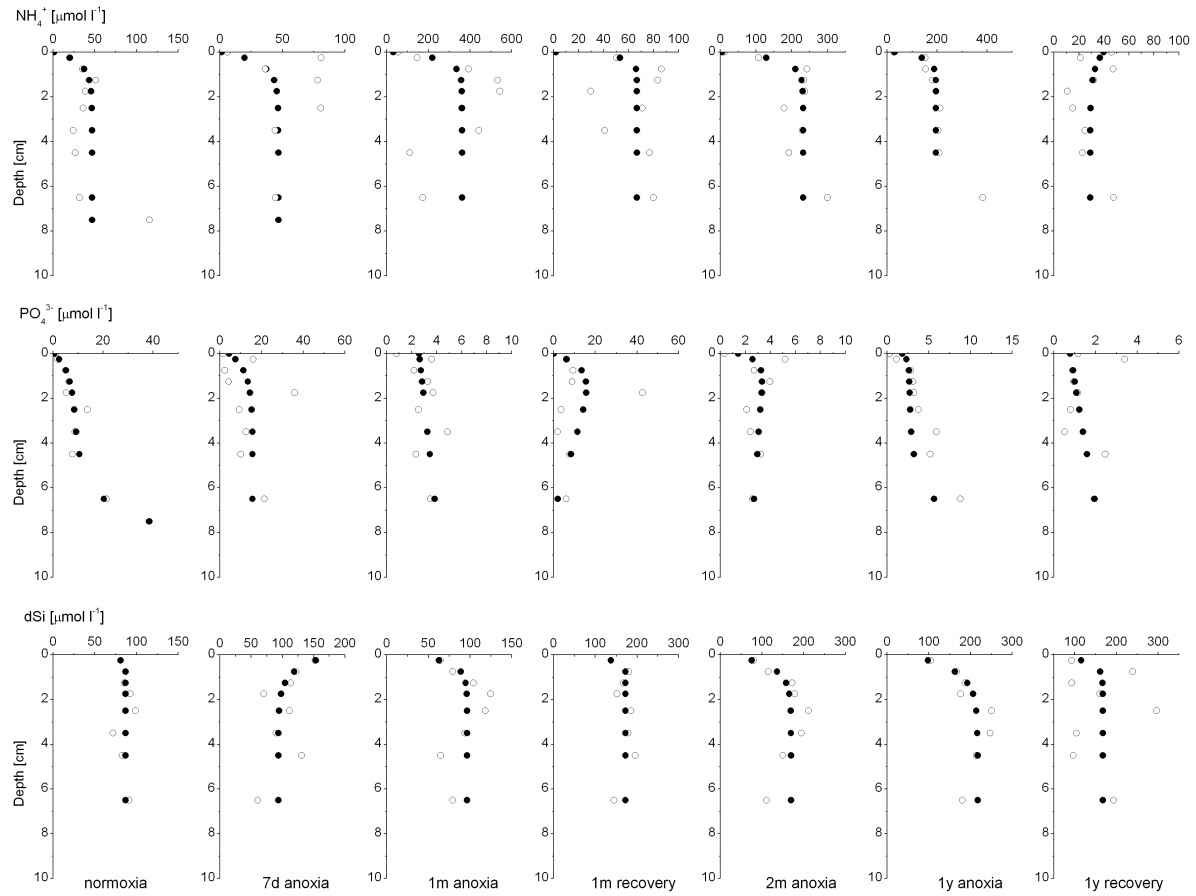

Fig. 2. Depth profiles of pore water $\mathrm{NH}_{4}^{+}, \mathrm{PO}_{4}^{3-}$ and dSi together with model calculation data during various experiments in the Gulf of Trieste. Measured data - white dots; model calculation data - black dots.

\section{BGD}

10, 11729-11755, 2013

Diagenesis and benthic fluxes of nutrients and metals

N. Koron et al.

\section{Title Page}

\section{Abstract \\ Introduction \\ Conclusions \\ References}

Tables

Figures

14

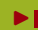

4

Back

Close

Full Screen / Esc

Printer-friendly Version

Interactive Discussion 


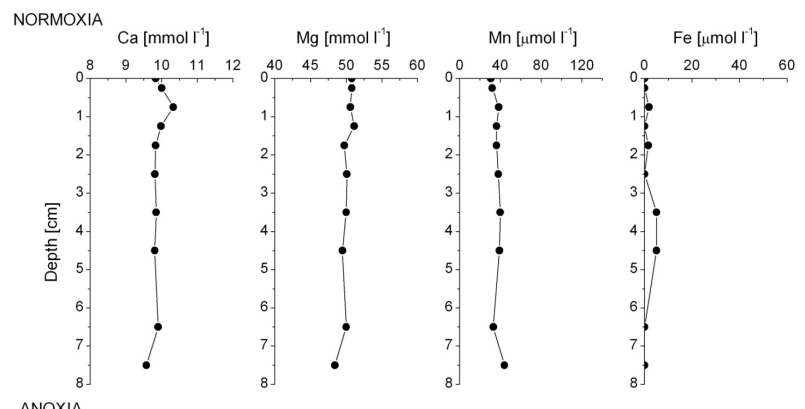

BGD

10, 11729-11755, 2013

ANOXIA
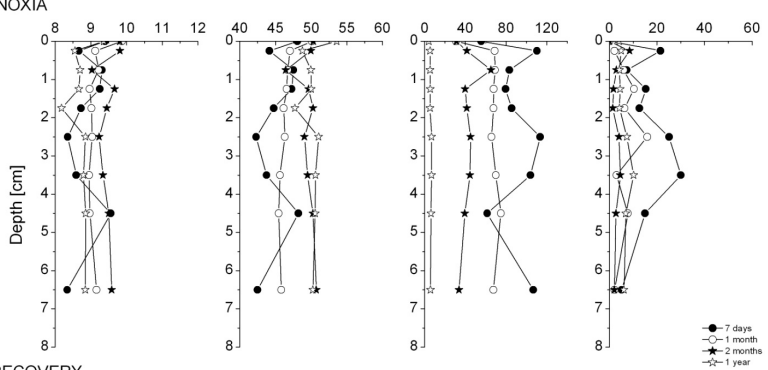

Title Page

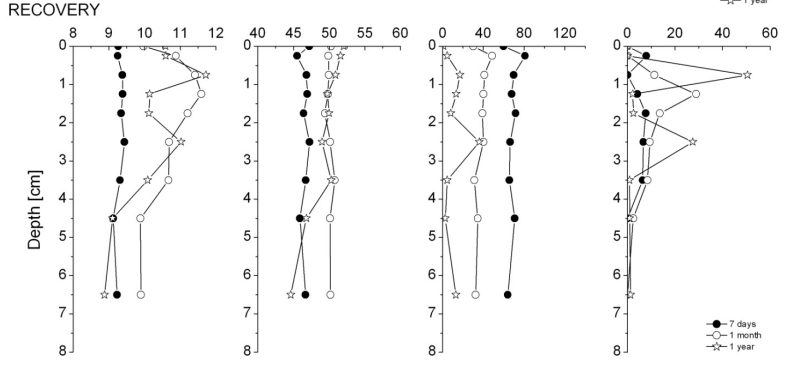

Diagenesis and benthic fluxes of nutrients and metals

N. Koron et al.

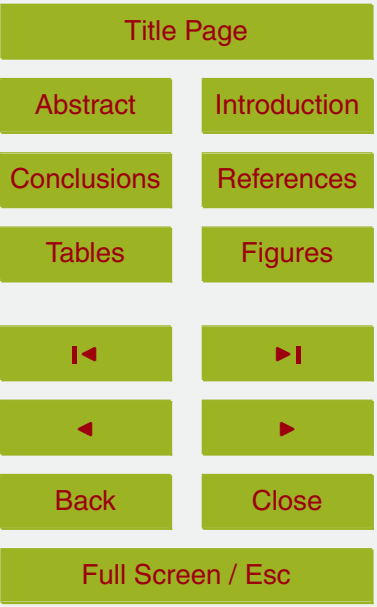

Printer-friendly Version

Fig. 3. Depth profiles of $\mathrm{Ca}, \mathrm{Mg}, \mathrm{Mn}$ and $\mathrm{Fe}$ in pore waters during normoxic-anoxic-reoxic experiments performed in the Gulf of Trieste.

Interactive Discussion 